\title{
Human sex hormone-binding globulin does not provide metabolic protection against diet-induced obesity and dysglycemia in mice
}

\author{
Yael Sofer ${ }^{1}$, Nava Nevo' ${ }^{2}$ Michal Vechoropoulos' ${ }^{1}$, Gabi Shefer', Etty Osher', Nathan Landis', Karen Tordjman', \\ Geoffrey L Hammond ${ }^{3}$ and Naftali Stern' ${ }^{1}$ \\ ${ }^{1}$ Institute of Endocrinology, Metabolism and Hypertension, Tel Aviv-Sourasky Medical Center, Sackler Faculty of Medicine, Tel Aviv University, Tel \\ Aviv, Israel \\ ${ }^{2}$ Department of Biological Regulation, Weizmann Institute of Science, Rehovot, Israe \\ ${ }^{3}$ Departments of Cellular \& Physiological Sciences and Obstetrics \& Gynaecology, University of British Columbia, Vancouver, British Columbia, Canada \\ Correspondence should be addressed to N Stern: naftalis@tlvmc.gov.il
}

\begin{abstract}
Background: Sex hormone-binding globulin (SHBG) is the main transporter of sex hormones in most vertebrates. Low SHBG levels have been linked to increased risk for diabetes and metabolic syndrome. Polymorphisms of the SHBG gene linked to low SHBG protein levels also strongly predicted increased risk of type 2 diabetes, thus raising the possibility that SHBG may play a role in the pathogenesis of insulin resistance and diabetes.

Aim: To examine whether expression of human SHBG in mice may ameliorate the development of diabetes and metabolic syndrome in response to a high-fat diet (HFD). Methods: Transgene mice expressing a human SHBG transgene (SHBG+) $(N=10 / 11$; males/ females) and their wild type littermates $(N=12 / 8$; males/females) were fed HFD for 4.5 months.

Results: HFD induced comparable obesity in control and $S H B G+$ mice. Male transgenes had higher muscle mass after $2-3.5$ months HFD $(0.43 \pm 0.028(n=4)$ vs $0.38 \pm 0.053 \mathrm{~g}$ $(n=7), P=0.05)$. Fasting blood glucose, as well as insulin or HOMA-IR, was not different in transgenic vs wild-type males after 4-5 months HFD. Female transgenes had higher fasting glucose $(152 \pm 29(n=7)$ vs $115 \pm 27 \mathrm{mg} / \mathrm{dL}, P=0.01(n=8))$, but mean insulin and HOMA-IR were not different. Likewise, insulin tolerance test and intra-peritoneal glucose tolerance test (GTT) were not different. Finally, $S H B G+$ mice were not different from controls in terms of liver enzymes, serum triglyceride levels and blood pressure. Conclusion: In mice with diet-induced obesity, human SHBG did not protect against development of obesity or dysglycemia.
\end{abstract}

\author{
Key Words \\ - SHBG \\ - diabetes \\ - metabolic syndrome
}

\section{Introduction}

SHBG is a homodimeric plasma glycoprotein produced by the liver that acts as the main transporter of active estrogens and androgens in almost all vertebrates (1). The protein has high affinity and selectivity to these sex steroids, and it has been traditionally postulated that the role of SHBG is limited to the transport of sex steroids into the target cells $(2,3)$. However, it has also been reported that SHBG interacts with a trans-membrane receptor that activates cellular cascades after binding sex steroids $(4,5)$.

The relation between low SHBG levels and diabetes now appears well established, both in men and women $(6,7,8)$ and remains significant even after adjustment

$$
\begin{array}{lr}
\text { http://www.endocrineconnections.org } & \text { @ } 2018 \text { The authors } \\
\text { https://doi.org/10.1530/EC-17-0240 } & \text { Published by Bioscientifica Ltd }
\end{array}
$$

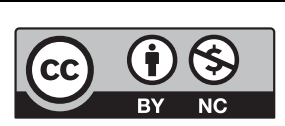

This work is licensed under a Creative Commons Attribution-NonCommercial 4.0 International License. 
for BMI (9, 10, 11) and waist circumference (12). A meta-analysis of more than ten prospective studies has demonstrated that women with SHBG levels higher than $60 \mathrm{nmol} / \mathrm{L}$ had $80 \%$ lower risk of type 2 diabetes (7). Men with SHBG higher than $28.3 \mathrm{nmol} / \mathrm{L}$ had a $52 \%$ smaller risk of developing diabetes (7). High SHBG levels are apparently also associated with lower incidence of insulin resistance in men (10). Furthermore, crosssectional studies in non-diabetic men and women have shown an inverse relationship between SHBG levels and HbA1c $(11,13)$. Hypoandrogenism in men and hyperandrogenism in women (e.g., the polycystic ovary syndrome) have been linked to insulin resistance and the metabolic syndrome $(13,14)$. In one report, SHBG levels predicted the development of gestational diabetes as early as 11-13 weeks of gestation (15). Of note, several studies have shown that the relationship between SHBG levels and diabetes is independent of sex hormones, in both female and male subjects $(16,17,18)$. In a few studies, SHBG has also been linked to the metabolic syndrome in both adolescents $(19,20)$ and adults $(21)$. Other metabolic components such as liver fat have also been strongly and inversely correlated with SHBG levels (22). Favorable lifestyle changes caused a parallel regression of fatty liver and increase in plasma levels of SHBG (23). A few studies have suggested that elevated insulin levels suppress SHBG production $(24,25)$, and insulin-sensitizing drugs, such as metformin and thiazolidinediones, have been shown to increase SHBG levels in men and women $(26,27)$. Other studies have shown that dietary monosaccharides can decrease $S H B G$ expression (28).

There is evidence that SHBG levels may be influenced by specific polymorphisms in the SHBG gene per se and also by an array of loci in genes involved in biologic networks such as liver function, lipid metabolism, glucose metabolism, androgen and estrogen receptor function and epigenetic effects (29). Recent studies have also shown that specific genetic polymorphisms of $S H B G$ were not only predictive of SHBG protein levels, but also of the apparently consequent risk of type 2 diabetes in men and women $(12,30)$. Also, one study suggested an association between a polymorphism in the $S H B G$ promoter and polycystic ovary syndrome (31). Collectively, these findings are consistent with the hypothesis that the SHBG protein may not only comprise a 'reverse' biomarker of insulin resistance and diabetes, but could curb their evolution (32). To directly address this question, we examined whether or not mice expressing human SHBG have attenuated tendency to develop diabetes and other characteristics of the metabolic syndrome.

\section{Materials and methods}

High-fat diet-fed mice

Animal care and experiments were approved by the Institutional Animal Care and Use Committee of the Tel Aviv University. Twenty C57Bl/6J WT and twenty transgene littermates (non-congenic) expressing a $4 \mathrm{~kb}$ human $S H B G$ transgene under the control of its own promoter sequence (33) were separated by sex at age 3 weeks and at age 6 weeks were placed on a high-fat diet (HFD, Research Diets, Inc, New Brunswick, NJ, USA). The diet was composed of $58 \%$ fat from lard, $25.6 \%$ carbohydrate and $16.4 \%$ protein (total caloric value, $23.4 \mathrm{~kJ} / \mathrm{g}$ ). Weight of mice was checked weekly. Identification of transgenic mice was done using PCR for human $S H B G$, as described previously (32). DNA was extracted from mice tails using REDExtract-N-Amp Tissue PCR Kit. Thereafter, the DNA was subjected to PCR amplification $\left(1\right.$ cycle of $95^{\circ} \mathrm{C}$ for $2 \mathrm{~min}, 40$ cycles of $94^{\circ} \mathrm{C}$ for $30 \mathrm{~s}, 64^{\circ} \mathrm{C}$ for $30 \mathrm{~s}$ and $72^{\circ} \mathrm{C}$ for $30 \mathrm{~s}$ ) using specific forward (5'-GATCCCCAGAGGGGTGATAGC-3') and reverse (5'-GGGTAAAGGAAACAGGGGCAC-3') primers designed to amplify a 153-bp region in the human $S H B G$ promoter (34).

Further validation of the model was done by measuring serum SHBG (Siemens 06603393 Immulite SHBG Kit). After 20 weeks of the HFD, blood samples were collected for the measurement of fasting glucose, insulin, lipids, liver enzymes and testosterone levels. A glucose tolerance test (GTT) was done after an overnight fast with an intraperitoneal injection of glucose $(2 \mathrm{mg} / \mathrm{kg})$. Glucose was measured at the following time points: $0,15,30,60,90$ and 120 min after the injection of glucose. Similarly, an insulin tolerance test (ITT) was carried out with an intra-peritoneal injection of insulin (Humalog, $0.75 \mathrm{U} / \mathrm{kg}$; Eli Lilly) and subsequent measurement of glucose at same time points. Blood pressure was measured in awake mice by a noninvasive approach using a three-channel computerized tail-cuff method $(35,36)$. The recording system consisted of an animal restrainer, which had a sensor block containing a photoelectric sensor built inside an occlusion cuff, an inflation bulb, a sphygmomanometer, an amplifier (model 3M229 BP, attached to the 31BP software package, IITC, Inc. Woodland Hills, CA, USA) and a chart recorder.

\section{Technical procedures}

\section{Assays}

Serum insulin was determined using a radioimmunoassay Insulin-CT (MP Biomedicals, Orangeburg, NY) with

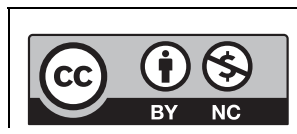

This work is licensed under a Creative Commons Attribution-NonCommercial 4.0 International License. 
a limit of detection of $3 \mu \mathrm{IU} / \mathrm{mL}$ at $95 \%$ confidence interval, measuring range from 5 to $25 \mu \mathrm{IU} / \mathrm{mL}$; intraassay CV being $7.6 \%$ and inter-assay CV BEING $8.9 \%$. Testosterone was measured with the Siemens ADVIA Centaur Testosterone system with a limit of detection of $0.025 \mathrm{ng} / \mathrm{mL}$; measuring range $0.025-15.0 \mathrm{ng} / \mathrm{mL}$; intra-assay $\mathrm{CV}$ of $6 \%$ and inter-assay $\mathrm{CV}$ of $9 \%$. SHBG was measured with the two-site chemiluminescent immunometric assay (Siemens IMMULITE 2000), with a detection limit of $0.8 \mathrm{nmol} / \mathrm{L}$, detection range reaching $100 \mathrm{nmol} / \mathrm{L}$ and intra/inter-assay $\mathrm{CV}<5.5 \%$ and $6.6 \%$, respectively. Muscle mass was measured using PIXImus II Densitometer (L4unar, Madison, WI, USA), which utilizes dual-energy X-ray absorptiometry (DEXA) technology.

\section{Statistical analysis}

Statistical calculations were carried out using 'Statistica 12' software (Statsoft, Inc). Statistical analyses were performed using 2-tailed Student's $t$ test, Mann-Whitney $U$ test and Kolmogorov-Smirnov test. A $P$ value less than 0.05 was considered significant. Data are presented as mean \pm s.D. Calculation of the area under the curve for measured responses has been described elsewhere (37).

\section{Results}

\section{Validation of the model}

Because mice and rats do not postnatally express Shbg in the liver, which is the site of production of circulating SHBG in other mammals such as humans, circulation testosterone in these rodents are generally low and tend to exhibit large fluctuations, presumably owing to the lack of the buffering effect afforded by SHBG (32). Expectedly, on the background of the previously described large variability in circulating testosterone in wild-type mice, serum total testosterone levels were much higher in female $S H B G$ transgenic mice as compared to wild-type mice. Indeed, testosterone levels were undetectable in
5 of 6 wild-type females, with the exception of one female mouse showing a value of $0.82 \mathrm{ng} / \mathrm{mL}$. In contrast, in the 10 female $S H B G$ transgenic mice, the mean testosterone level was $1.47 \pm 1.57 \mathrm{ng} / \mathrm{mL}$. Male $S H B G$ transgenes had non-significantly higher testosterone levels than the wildtype mice $(5.77 \pm 6.09 \mathrm{ng} / \mathrm{mL} ;(n=12)$ vs $2.31 \pm 4.31 \mathrm{ng} / \mathrm{mL}$ $(n=11))$, owing to the large spread of testosterone levels in both strains. There was a $100 \%$ concordance between the presence of a human $S H B G$ gene as detected by PCR and the presence of measurable serum SHBG levels (data not shown). Concordantly, SHBG levels were undetectable in wild-type mice.

\section{Effect of SHBG expression on weight gain and body composition on HFD}

There was no significant difference in the initial weight of $S H B G$-expressing mice as compared to wild-type littermates. Further, weight gain on HFD and weight were similar throughout the experiment (data not shown). In male mice, median peak weight ( 4 months) was $48.3 \pm 2.87 \mathrm{~g}$ and $50.2 \pm 5.72 \mathrm{~g}$ for WT and $S H B G+$, respectively, and the corresponding attained mean weights for female mice were $45.5 \pm 7.4 \mathrm{~g}$ and $40.0 \pm 8.7 \mathrm{~g}$ ( $P=\mathrm{ns}$, for both comparisons).

Due to the known association between total testosterone and muscle (38), we compared muscle and fat mass of the gastrocnemius muscle, using dual-energy X-ray absorptiometry (DEXA). Male transgenes had significantly higher muscle mass after 3.5-month HFD, $0.68 \pm 019$ (median 0.67 ) $\mathrm{g} / \mathrm{cm}^{2}$, as compared to $0.43 \pm 0.1$ (median 0.38$) \mathrm{g} / \mathrm{cm}^{2}$, respectively $(P=0.032)$, but this difference was reversed after 5 months (Table 1). Bone mineral density and \% fat were not different between transgenes and controls. In HFD female mice, \% fat and muscle mass was not related to the SHBG status: WT mean muscle mass $0.3125 \pm 0.07 \mathrm{~g} / \mathrm{cm}^{2}$ (median 0.295) $(n=4)$ as compared with $S h b g+$ mean muscle mass $0.413 \pm 0.1 \mathrm{~g} / \mathrm{cm}^{2}$ (median 0.37) $(n=3)$. WT mean \% fat is $33.12 \pm 4.08$

Table 1 Muscle mass $\left(\mathrm{g} / \mathrm{cm}^{2}\right)$ and \% fat of gastrocnemius in male wild-type (WT) and SHBG+ mice after HFD.

\begin{tabular}{|c|c|c|}
\hline \multirow[b]{2}{*}{$\begin{array}{l}\text { Duration } \\
\text { HFD }\end{array}$} & \multicolumn{2}{|c|}{2 months } \\
\hline & $\begin{array}{l}\text { Muscle mass mean } \\
\text { (median) }\left(\mathrm{g} / \mathrm{cm}^{2}\right)\end{array}$ & \%FAT mean (median) \\
\hline WT & $\begin{array}{c}0.39 \pm 0.05(0.38) \\
n=7\end{array}$ & $\begin{array}{c}21.89 \pm 10(16.23) \\
n=7\end{array}$ \\
\hline$S H B G+$ & $\begin{array}{c}0.43 \pm 0.03(0.43) \\
n=4\end{array}$ & $\begin{array}{c}27.58 \pm 9.48(32.36) \\
n=4\end{array}$ \\
\hline$P$ & NS & NS \\
\hline
\end{tabular}

http://www.endocrineconnections.org https://doi.org/10.1530/EC-17-0240

\begin{tabular}{|c|c|}
\hline \multicolumn{2}{|c|}{3.5 months } \\
\hline $\begin{array}{c}\text { Muscle mass mean } \\
\text { (median) }\left(\mathrm{g} / \mathrm{cm}^{2}\right)\end{array}$ & \%FAT mean (median) \\
\hline $\begin{array}{c}0.43 \pm 0.1(0.38) \\
n=3\end{array}$ & $\begin{array}{c}24.76 \pm 3.4(27.04) \\
n=3\end{array}$ \\
\hline $\begin{array}{c}0.68 \pm 0.19(0.67) \\
n=6 \\
0.032\end{array}$ & $\begin{array}{c}34.42 \pm 11.3(32.21) \\
n=6 \\
0.065\end{array}$ \\
\hline
\end{tabular}

(c) 2018 The authors Published by Bioscientifica Ltd

\begin{tabular}{cc}
\hline \multicolumn{2}{c}{$\mathbf{5}$ months } \\
\hline Muscle mass & \\
$\frac{\text { mean }(\text { median })\left(\mathrm{g} / \mathrm{cm}^{2}\right)}{0.48 \pm 0.02(0.49)}$ & $\frac{25 A T \text { mean (median) }}{25.94 \pm 2.55(27.13)}$ \\
$n=3$ & $n=3$ \\
$0.39 \pm 0.09(0.37)$ & $21.12 \pm 7.7(23.79)$ \\
$n=8$ & $n=8$ \\
0.02 & 0.097 \\
\hline
\end{tabular}

This work is licensed under a Creative Commons Attribution-NonCommercial 4.0 International License. 
Table 2 Glucose metabolism in female mice 4.5 months on HFD.

\begin{tabular}{|c|c|c|c|c|}
\hline & Weight (g) mean (median) & Fasting glucose (mg/dL) mean (median) & Insulin (IU/L) mean (median) & HOMA-IR mean (median) \\
\hline WT $(n=8)$ & $35.66 \pm 4.43(34.99)$ & $115 \pm 27(102)$ & $15 \pm 4 *(15)$ & $4.28 \pm 1.43 *(4.85)$ \\
\hline$S H B G+(n=7)$ & $42.3 \pm 3.41(101.5)$ & $152 \pm 29(152)$ & $48 * * \pm 32(44)$ & $16.89 \pm 8.80 * *(17.03)$ \\
\hline$P$ & 0.0082 & 0.014 & 0.13 & 0.007 \\
\hline
\end{tabular}

$* n=6 ; * * n=4$

This outcome has some similarities and major differences compared to the human data. First, the presence of SHBG did not prevent weight gain on HFD in our experiments. In humans, higher SHBG levels appear to confer protection from diabetes after adjustment for the level of obesity (12). Phrased alternatively, in humans, SHBG is linked to lesser risk for diabetes even in the obese state $(12,31)$. Second, in contrast to what might have been expected based on the human data, high circulating SHBG levels did not protect mice fed on a HFD from diabetes. Unlike humans, SHBG does not circulate in adult rodents (39). Despite early interest in a putative cellular receptor for SHBG (41), evidence for its physiological role is lacking. Therefore, the possibility that SHBG's putative protective metabolic effect can be exerted by some direct interaction with cellular target sites/receptors to enhance insulin sensitivity remains entirely speculative.

In a recent report (42), crossbreeding of the same $S H B G+$ transgenic mouse used in our study with the $\mathrm{db}-$ $\mathrm{db}$ transgenic mice lacking the leptin receptor, attenuated the massive weight gain seen in the latter mouse model, but did not affect the metabolic anomalies seen in this setting, i.e., high glucose and increased serum lipid levels. The latter is in general agreement with our results, in that neither baseline nor post-HFD glucose and triglycerides differed between $S H B G+$ and wild-type mice in the obese state.

Whether the linkage of SHBG to dysglycemia and diabetes in humans is species specific or mediated by some mechanism that is not operative in the HFD mouse model cannot be determined based on our experiments. Our data are limited to a particular animal model under a particular experimental set of metabolic conditions (HFD). Hence, we are unable to extrapolate our results to the much more complex clinical setting in humans, where genetics, nutrition, environment, life style and aging all interact in the pathogenesis of diabetes. Nevertheless, our results do not support the concept that SHBG expression alone modifies the abnormalities in glucose metabolism, which are linked to HFD and the associated obese state.

$$
\begin{aligned}
& \text { http://www.endocrineconnections.org } \\
& \text { https://doi.org/10.1530/EC-17-0240 }
\end{aligned}
$$

(C) 2018 The authors Published by Bioscientifica Ltd
This work is licensed under a Creative Commons Attribution-NonCommercial 4.0 International License. 


\section{Declaration of interest}

The authors declare that there is no conflict of interest that could be perceived as prejudicing the impartiality of the research reported.

\section{Funding}

The work was supported by the Sagol Foundation for the Metabolic Syndrome Research Center at TASMC and by Dr Sofer's TASMC research grant for excellence in research.

\section{References}

1 Hammond GL. Diverse roles for sex hormone-binding globulin in reproduction. Biology of Reproduction 201185 431-441. (https://doi. org/10.1095/biolreprod.111.092593)

2 Hammond GL, Wu TS \& Simard M. Evolving utility of sex hormonebinding globulin measurements in clinical medicine. Current Opinion in Endocrinology, Diabetes and Obesity 201219 183-189. (https://doi. org/10.1097/MED.0b013e328353732f)

3 Anderson DC. Clinical Endocrinology 19743 69-96. (https://doi. org/10.1111/j.1365-2265.1974.tb03298.x)

4 Rosner W, Hryb DJ, Kahn SM, Nakhla AM \& Romas NA. Interactions of sex hormone-binding globulin with target cells. Molecular and Cellular Endocrinology 2010316 79-85. (https://doi.org/10.1016/j. mce.2009.08.009)

5 De Toni L, Guidolin D, De Filippis V, Tescari S, Strapazzon G, Santa Rocca M, Ferlin A, Plebani M \& Foresta C. Osteocalcin and sex hormone binding globulin compete on a specific binding site of GPRC6A. Endocrinology 2016157 4473-4486. (https://doi. org/10.1210/en.2016-1312)

6 Haffner SM. Sex hormone-binding protein, hyperinsulinemia, insulin resistance and noninsulin-dependent diabetes. Hormone Research 199645 233-237. (https://doi.org/10.1159/000184794)

7 Ding EL, Song Y, Malik VS, Liu S. Siiteri PK, Murai JT, Hammond GL, Nisker JA, Raymoure WJ \& Kuhn RW. Sex differences of endogenous sex hormones and risk of type 2 diabetes: a systematic review and meta-analysis. JAMA 2006295 1288-1299. (https://doi.org/10.1001/ jama.295.11.1288)

8 Wang Q, Kangas AJ, Soininen P, Tiainen M, Tynkkynen T, Puukka K, Ruokonen A, Viikari J, Kähönen M, Lehtimäki T, et al. Sex hormonebinding globulin associations with circulating lipids and metabolites and the risk for type 2 diabetes: observational and causal effect estimates. International Journal of Epidemiology 201544 623-637. (https://doi.org/10.1093/ije/dyv093)

9 Muller M, Grobbee DE, den Tonkelaar I, Lamberts SW \& van der Schouw YT. Endogenous sex hormones and metabolic syndrome in aging men. Journal of Clinical Endocrinology and Metabolism 200590 2618-2623. (https://doi.org/10.1210/jc.2004-1158)

10 Brand JS, Wareham NJ, Dowsett M, Folkerd E, van der Schouw YT, Luben RN \& Khaw KT. Associations of endogenous testosterone and SHBG with glycated haemoglobin in middle-aged and older men. Clinical Endocrinology 201174 572-578. (https://doi.org/10.1111/ j.1365-2265.2010.03951.x)

11 Page-Wilson G, Goulart AC \& Rexrode KM. Interrelation between sex hormones and plasma sex hormone-binding globulin and hemoglobin A1c in healthy postmenopausal women. Metabolic Syndrome and Related Disorders 20097 249-254. (https://doi. org/10.1089/met.2008.0081)

12 Ding EL, Song Y, Manson JE, Hunter DJ, Lee CC, Rifai N, Buring JE, Gaziano JM \& Liu S. Sex hormone-binding globulin and risk of type 2 diabetes in women and men. New England Journal of Medicine 2009361 1152-1163. (https://doi.org/10.1056/ NEJMoa0804381)
13 Andersson B, Märin P, Lissner L, Vermeulen A \& Björntorp P. Testosterone concentrations in women and men with NIDDM. Diabetes Care 199417 405-411. (https://doi.org/10.2337/ diacare.17.5.405)

14 Yang R, Yang S, Li R, Liu P, Qiao J \& Zhang Y. Effects of hyperandrogenism on metabolic abnormalities in patients with polycystic ovary syndrome: a meta-analysis. Reproductive Biology and Endocrinology 201614 67. (https://doi.org/10.1186/s12958-016-0203-8)

15 Nanda S, Savvidou M, Syngelaki A, Akolekar R \& Nicolaides KH. Prediction of gestational diabetes mellitus by maternal factors and biomarkers at 11 to 13 weeks. Prenatal Diagnosis 201031 135-141. (https://doi.org/10.1002/pd.2636)

16 Lakshman KM, Bhasin S \& Araujo AB. Sex hormone-binding globulin as an independent predictor of incident type 2 diabetes mellitus in men. Journal of Gerontology, Series A: Biological Sciences and Medical Sciences 201065 503-509. (https://doi.org/10.1093/gerona/glq002)

17 Vikan T, Schirmer H, Njølstad I \& Svartberg J. Low testosterone and sex hormone-binding globulin levels and high estradiol levels are independent predictors of type 2 diabetes in men. European Journal of Endocrinology 2010162 747-754. (https://doi.org/10.1530/EJE-090943)

18 Kalyani RR, Franco M, Dobs AS, Ouyang P, Vaidya D, Bertoni A, Gapstur SM \& Golden SH. The association of endogenous sex hormones, adiposity, and insulin resistance with incident diabetes in postmenopausal women. Journal of Clinical Endocrinology and Metabolism 200994 4127-4135. (https://doi.org/10.1210/jc.20090910)

19 Agirbasli M, Agaoglu NB, Orak N, Caglioz H, Ocek T, Poci N, Salaj A \& Maya S. Sex hormones and metabolic syndrome in children and adolescents. Metabolism 200958 1256-1262. (https://doi. org/10.1016/j.metabol.2009.03.024)

20 Glueck CJ, Morrison JA, Daniels S, Wang P \& Stroop D. Sex hormonebinding globulin, oligomenorrhea, polycystic ovary syndrome, and childhood insulin at age 14 years predict metabolic syndrome and class III obesity at age 24 years. Journal of Pediatrics 2011159 308-313. (https://doi.org/10.1016/j.jpeds.2011.01.018)

21 Li C, Ford ES, Li B, Giles WH \& Liu S. Association of testosterone and sex hormone-binding globulin with metabolic syndrome and insulin resistance in men. Diabetes Care 201033 1618-1624. (https://doi. org/10.2337/dc09-1788)

22 Jaruvongvanich V, Sanguankeo A, Riangwiwat T \& Upala S. Testosterone, sex hormone-binding globulin and nonalcoholic fatty liver disease: a systematic review and meta-analysis. Annals of Hepatology 201716 382-394. (https://doi. org/10.5604/16652681.1235481)

23 Peter A, Kantartzis K, Machann J, Schick F, Staiger H, Machicao F, Schleicher E, Fritsche A, Häring HU \& Stefan N. Relationships of circulating sex hormone-binding globulin with metabolic traits in humans. Diabetes 201059 3167-3173. (https://doi.org/10.2337/ db10-0179)

24 Plymate SR, Matej LA, Jones RE \& Friedl KE. Inhibition of sex hormone-binding globulin production in the human hepatoma (Hep G2) cell line by insulin and prolactin. Journal of Clinical Endocrinology and Metabolism 199867 460-464. (https://doi.org/10.1210/jcem-673-460)

25 Nestler JE, Powers LP, Matt DW, Steingold KA, Plymate SR, Rittmaster RS, Clore JN \& Blackard WG. A direct effect of hyperinsulinemia on serum sex hormone-binding globulin levels in obese women with the polycystic ovary syndrome. Journal of Clinical Endocrinology and Metabolism 199172 83-89. (https://doi. org/10.1210/jcem-72-1-83)

26 Pasquali R, Gambineri A, Biscotti D, Vicennati V, Gagliardi L, Colitta D, Fiorini S, Cognigni GE, Filicori M \& Morselli-Labate AM. Effect of long-term treatment with metformin added to hypocaloric diet on body composition, fat distribution, and androgen and insulin levels in abdominally obese women with and without the polycystic 
ovary syndrome. Journal of Clinical Endocrinology and Metabolism 2000 85 2767-2774. (https://doi.org/10.1210/jcem.85.8.6738)

27 Dunaif A, Scott D, Finegood D, Quintana B \& Whitcomb R. The insulin-sensitizing agent troglitazone improves metabolic and reproductive abnormalities in the polycystic ovary syndrome. Journal of Clinical Endocrinology and Metabolism 199681 3299-3306. (https:// doi.org/10.1210/jcem.81.9.8784087)

28 Selva DM, Hogeveen KN, Innis SM \& Hammond GL. Monosaccharide-induced lipogenesis regulates the human hepatic sex hormone-binding globulin gene. Journal of Clinical Investigation 2007117 3979-3987. (https://doi.org/10.1172/JCI32249)

29 Coviello AD, Haring R, Wellons M, Vaidya D, Lehtimäki T, Keildson S, Lunetta KL, He C, Fornage M, Lagou V, et al. A genomewide association meta-analysis of circulating sex hormone-binding globulin reveals multiple Loci implicated in sex steroid hormone regulation. PLoS Genetics 20128 e1002805. (https://doi.org/10.1371/ journal.pgen.1002805)

30 Perry JR, Weedon MN, Langenberg C, Jackson AU, Lyssenko V, Sparsø T, Thorleifsson G, Grallert H, Ferrucci L, Maggio M, et al. Genetic evidence that raised sex hormone binding globulin (SHBG) levels reduce the risk of type 2 diabetes. Human Molecular Genetics 201019 535-544. (https://doi.org/10.1093/hmg/ddp522)

31 Xita N, Tsatsoulis A, Chatzikyriakidou A \& Georgiou I. Association of the (TAAAA)n repeat polymorphism in the sex hormone-binding globulin (SHBG) gene with polycystic ovary syndrome and relation to SHBG serum levels. Journal of Clinical Endocrinology and Metabolism 200388 5976-5980. (https://doi.org/10.1210/jc.2003-030197)

32 Le TN, Nestler JE, Strauss JF 3rd \& Wickham EP 3rd. Sex hormonebinding globulin and type 2 diabetes mellitus. Trends in Endocrinology and Metabolism 201223 32-40. (https://doi.org/10.1016/j. tem.2011.09.005)

33 Jänne M, Deol HK, Power SG, Yee SP \& Hammond GL. Human sex hormone-binding globulin gene expression in transgenic mice. Molecular Endocrinology 199812 123-136. (https://doi.org/10.1210/ mend.12.1.0050)

34 Jänne M \& Hammond GL. Hepatocyte nuclear factor-4 controls transcription from a TATA-less human sex hormone-binding globulin gene promoter. Journal of Biological Chemistry 1998273 34105-34114. (https://doi.org/10.1074/jbc.273.51.34105)

35 Yaden S, Palmer RT, Elko EE \& Lal H. Comparative activity of antihypertensive drugs as determined by indirect measurement of blood pressure. Drug Development Research 19855 129-136. (https:// doi.org/10.1002/ddr.430050205)

36 Whitesall SE, Hoff JB, Vollmer AP \& D'Alecy LG. Comparison of simultaneous measurement of mouse systolic arterial blood pressure by radiotelemetry and tail-cuff methods. American Journal of Physiology: Heart and Circulatory Physiology 2004286 2408-2415. (https://doi.org/10.1152/ajpheart.01089.2003)

37 Stern N, Sowers JR, Taylor IL \& Golub M. Dopaminergic modulation of meal-stimulated and circadian secretion of pancreatic polypeptide in man. Journal of Clinical Endocrinology and Metabolism 198356 300-304. (https://doi.org/10.1210/jcem-56-2-300)

38 Herbst KL \& Bhasin S. Testosterone action on skeletal muscle. Current Opinion in Clinical Nutrition and Metabolic Care 20047 271-277. (https://doi.org/10.1097/00075197-200405000-00006)

39 Gunsalus GL, Musto NA \& Bardin W. Immunoassay of androgen binding protein in blood: a new approach for study of the seminiferous tubule. Science 1978200 65-66. (https://doi. org/10.1126/science.635573)

40 Thaler MA, Seifert-Klauss V \& Luppa PB. The biomarker sex hormone-binding globulin - from established applications to emerging trends in clinical medicine. Best Practice and Research Clinical Endocrinology and Metabolism 201529 749-60. (https://doi. org/10.1016/j.beem.2015.06.005)

41 Fortunati N, Raineri M, Cignetti A, Hammond GL \& Frairia R. Control of the membrane sex hormone-binding globulinreceptor (SHBG-R) in MCF-7 cells: effect of locally produced SHBG. Steroids 199863 282-284. (https://doi.org/10.1016/S0039128X(98)00021-X)

42 Saéz-López C, Rivera-Giménez M, Hernández C, Simó R \& Selva DM. SHBG-C57BL/ksJ-db/db: a new mouse model to study SHBG expression and regulation during obesity development. Endocrinology 2015156 4571-4581. (https://doi.org/10.1210/ en.2015-1677)

Received in final form 19 October 2017

Accepted 15 November 2017

Accepted Preprint published online 15 November 2017 http://www.endocrineconnections.org https://doi.org/10.1530/EC-17-0240 (c) 2018 The authors Published by Bioscientifica Ltd

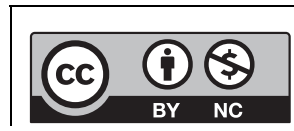

This work is licensed under a Creative Commons Attribution-NonCommercial 4.0 International License. 